\title{
SCJD Exam with J2SE 5 Second Edition
}

Andrew Monkhouse and Terry Camerlengo 


\section{SCJD Exam with J2SE 5, Second Edition}

\section{Copyright $\odot 2006$ by Andrew Monkhouse and Terry Camerlengo}

All rights reserved. No part of this work may be reproduced or transmitted in any form or by any means, electronic or mechanical, including photocopying, recording, or by any information storage or retrieval system, without the prior written permission of the copyright owner and the publisher.

ISBN (pbk): 1-59059-516-5

Printed and bound in the United States of America 987654321

Trademarked names may appear in this book. Rather than use a trademark symbol with every occurrence of a trademarked name, we use the names only in an editorial fashion and to the benefit of the trademark owner, with no intention of infringement of the trademark.

Lead Editor: Jason Gilmore

Technical Reviewer: Jim Yingst

Editorial Board: Steve Anglin, Dan Appleman, Ewan Buckingham, Gary Cornell, Tony Davis, Jason Gilmore, Jonathan Hassell, Chris Mills, Dominic Shakeshaft, Jim Sumser

Project Manager: Beth Christmas

Copy Edit Manager: Nicole LeClerc

Copy Editor: Liz Welch

Assistant Production Director: Kari Brooks-Copony

Production Editor: Lori Bring

Compositor: Dina Quan

Proofreader: Elizabeth Berry

Indexer: John Collin

Artist: Kinetic Publishing Services, LLC

Cover Designer: Kurt Krames

Manufacturing Director: Tom Debolski

Distributed to the book trade worldwide by Springer-Verlag New York, Inc., 233 Spring Street, 6th Floor, New York, NY 10013. Phone 1-800-SPRINGER, fax 201-348-4505, e-mail orders-ny@springer-sbm.com, or visit http://www. springeronline.com.

For information on translations, please contact Apress directly at 2560 Ninth Street, Suite 219, Berkeley, CA 94710. Phone 510-549-5930, fax 510-549-5939, e-mail info@apress.com, or visit http://www. apress.com.

The information in this book is distributed on an "as is" basis, without warranty. Although every precaution has been taken in the preparation of this work, neither the author(s) nor Apress shall have any liability to any person or entity with respect to any loss or damage caused or alleged to be caused directly or indirectly by the information contained in this work.

The source code for this book is available to readers at http://www. apress. com in the Source Code section. You will need to answer questions pertaining to this book in order to successfully download the code. 


\section{Contents at a Glance}

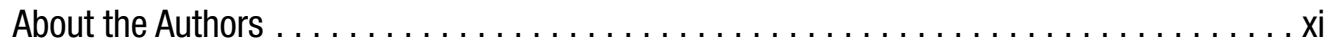

About the Technical Reviewer $\ldots \ldots \ldots \ldots \ldots \ldots \ldots \ldots \ldots \ldots \ldots \ldots \ldots \ldots \ldots \ldots \ldots \ldots \ldots \ldots \ldots \ldots$

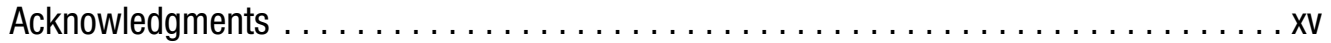

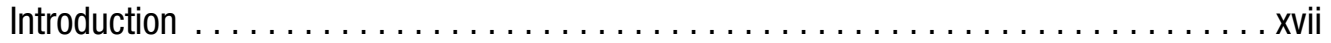

PART $1 \square \square$ Introduction and General Development Considerations

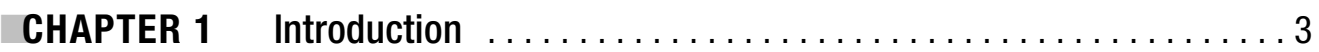

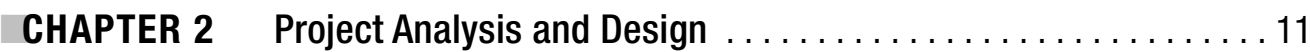

CHAPTER 3 Project Overview .......................... 57

\section{PART $2 \square \square=$ Implementing a J2SE Project}

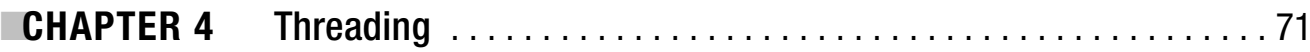

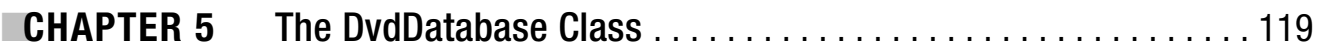

CHAPTER 6 Networking with RMI ........................ 163

CHAPTER 7 Networking with Sockets ...................... 199

CHAPTER 8 The Graphical User Interfaces $\ldots \ldots \ldots \ldots \ldots \ldots \ldots \ldots \ldots$

PART $3 \square \square=$ Wrap-Up

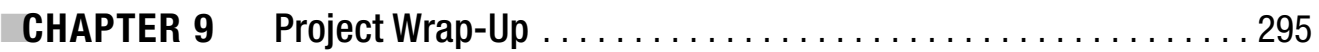

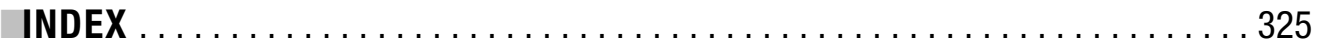




\section{Contents}

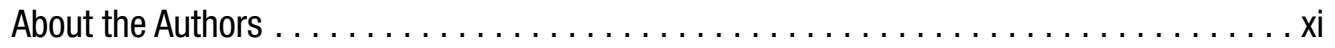

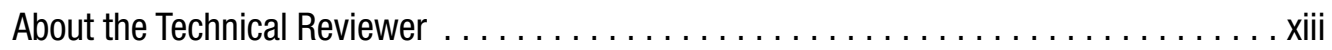

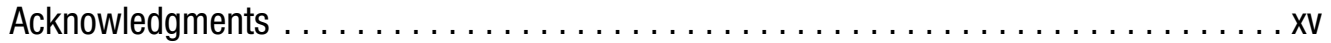

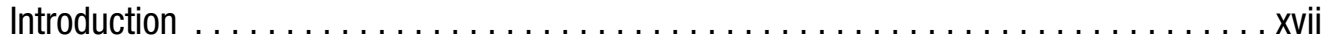

\section{PART $1=\square$ Introduction and General Development Considerations}

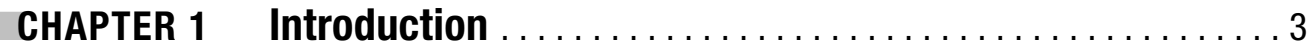

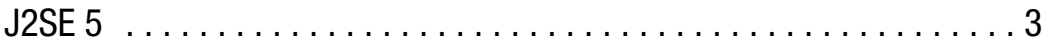

The SCJD Exam ............................... 4

The Certification Process $\ldots \ldots \ldots \ldots \ldots \ldots \ldots \ldots \ldots$

Downloading the Assignment ..................... 5

Documentation and Questions ..................... 5

Who Should Read This Book ........................ 6

About This Book ............................ 6

Setting Up the J2SE 5 JDK and Environmental Variables $\ldots \ldots \ldots \ldots 8$

Summary $\ldots \ldots \ldots \ldots \ldots \ldots \ldots \ldots \ldots \ldots \ldots \ldots \ldots, \ldots \ldots \ldots$

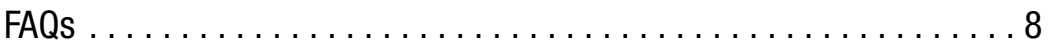

CHAPTER 2 Project Analysis and Design $\ldots \ldots \ldots \ldots \ldots \ldots \ldots \ldots \ldots$

Implementing a Project $\ldots \ldots \ldots \ldots \ldots \ldots \ldots \ldots \ldots \ldots \ldots 11$

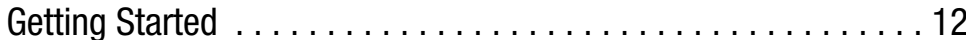

Gathering Requirements $\ldots \ldots \ldots \ldots \ldots \ldots \ldots \ldots \ldots 12$

Using Accepted Design Patterns . . . . . . . . . . . . . . . 14

Documenting Design Decisions . . . . . . . . . . . . . . . 15

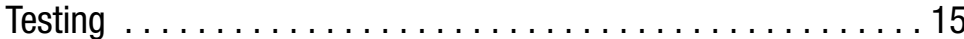

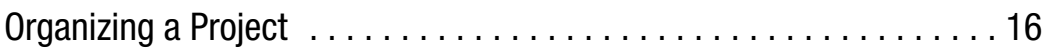

High-Level Documentation $\ldots \ldots \ldots \ldots \ldots \ldots \ldots \ldots \ldots \ldots \ldots$

Design Decisions Document ...................... 18 


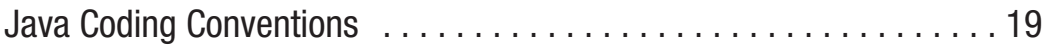

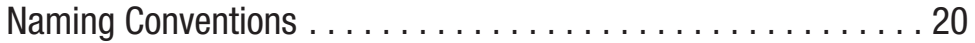

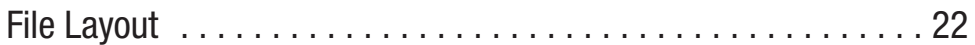

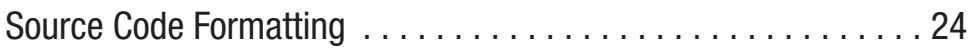

Formatting of Comments Within the Code ............. 28

Suggested Coding Conventions for New Features in JDK $5 \ldots 29$ Javadoc .35

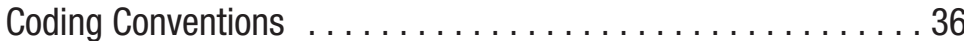

Working with Packages . . . . . . . . . . . . . . . . . 44

Best Practices . . . . . . . . . . . . . . . . . . . . . . . . 47

Writing Documentation As You Go . . . . . . . . . . . . 47

Assertions ............................49

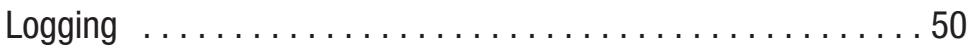

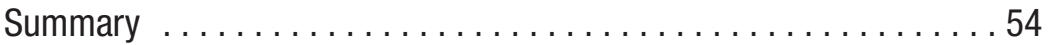

FAQs ........................................ 54

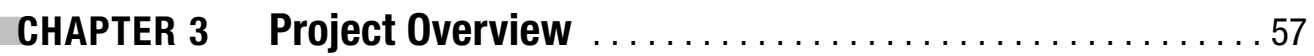

What Are the Essential Requirements for the Sun

Certification Project? . . . . . . . . . . . . . . . . . . . 57

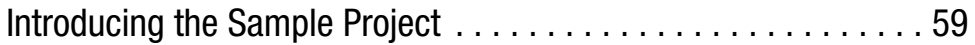

Application Overview ......................63

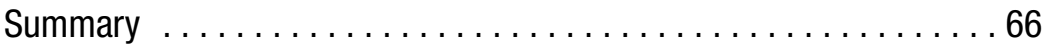

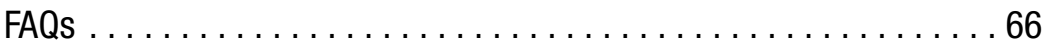

\section{PART $2 \square \square$ Implementing a J2SE Project}

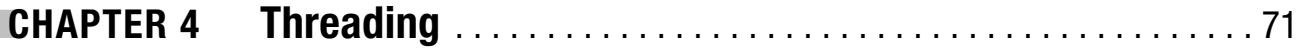

Threading Fundamentals . . . . . . . . . . . . . . . . . 71

A Brief Review of Threads . . . . . . . . . . . . . . . . 72

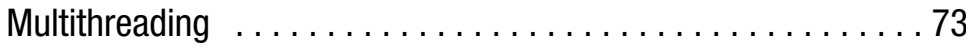

Java's Multithreading Concepts $\ldots \ldots \ldots \ldots \ldots \ldots \ldots 73$

Locks ............................... 87

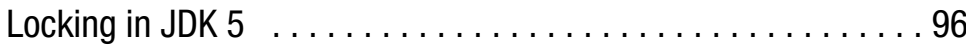

Locking Summary ...................... 98

Understanding Thread Safety $\ldots \ldots \ldots \ldots \ldots \ldots$

Deadlocks ............................. 98

Race Conditions ........................... 100

Starvation .................................. 102

Understanding Atomic Operations . . . . . . . . . . . . . . . 104 
Thread Safety Summary $\ldots \ldots \ldots \ldots \ldots \ldots \ldots \ldots \ldots$

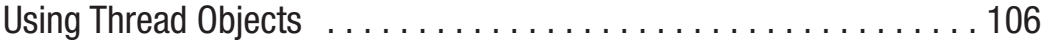

Stopping, Suspending, Destroying, and Resuming ....... 106

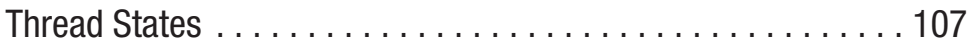

More on Blocking $\ldots \ldots \ldots \ldots \ldots \ldots \ldots \ldots \ldots \ldots \ldots$

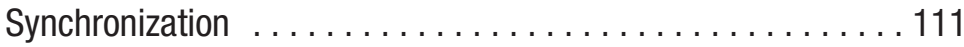

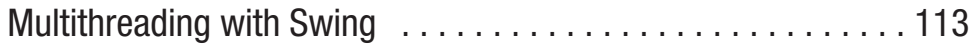

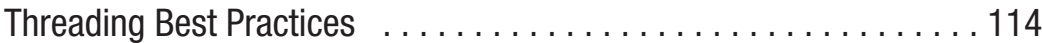

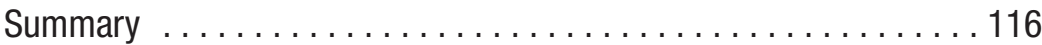

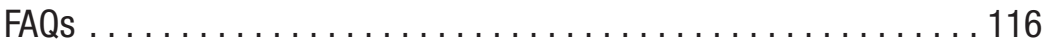

CHAPTER 5 The DvdDatabase Class $\ldots \ldots \ldots \ldots \ldots \ldots \ldots \ldots \ldots \ldots \ldots \ldots \ldots \ldots$

Creating the Classes Required for

the DvdDatabase Class . . . . . . . . . . . . . . . . . . . . . 119

The DVD Class: A Value Object $\ldots \ldots \ldots \ldots \ldots \ldots \ldots \ldots$

Discussion Point: Handling Exceptions Not Listed in the

Supplied Interface . . . . . . . . . . . . . . . 126

The DvdDatabase Class: A Façade . . . . . . . . . . . . . . . . 134

Accessing the Data: The DvdFileAccess Class . . . . . . . . . 137

Discussion Point: Caching Records . . . . . . . . . . . . . . 148

The ReservationsManager Class . . . . . . . . . . . . . . . . 148

Discussion Point: Identifying the Owner of the Lock . . . . . 150

Creating Our Logical Reserve Methods . . . . . . . . . . . . 154

The Logical Release Method . . . . . . . . . . . . . . . . 155

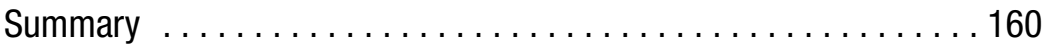

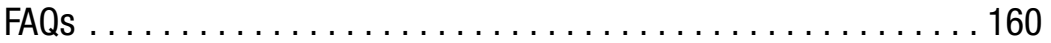

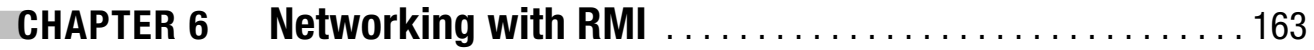

What Is Serialization? ............................ 164

Using the serialver Tool $\ldots \ldots \ldots \ldots \ldots \ldots \ldots \ldots \ldots \ldots$

The Serialization Process $\ldots \ldots \ldots \ldots \ldots \ldots \ldots \ldots \ldots 6$

Customizing Serialization with the Externalizable Interface . . . 169

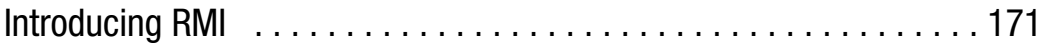

The Delivery Stack ....................... 173

The Pros and Cons of Using RMI as a Networking Protocol . . . 174

The Classes and Interfaces of RMI ............... 175

What is an RMl Factory? . . . . . . . . . . . . . . . . . 177

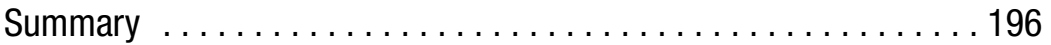

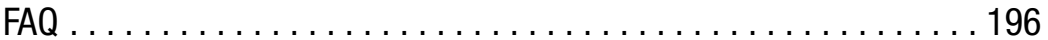


CHAPTER $7 \quad$ Networking with Sockets $\ldots \ldots \ldots \ldots \ldots \ldots \ldots \ldots \ldots$

Socket Overview ............................ 199

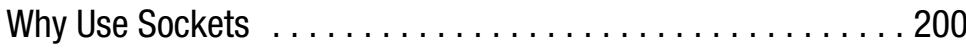

Socket Basics .............................. 200

Addresses ...........................200

TCP and UDP Sockets Overview . . . . . . . . . . . 201

TCP Socket Clients .......................... 203

The DvdSocketClient . . . . . . . . . . . . . . . . . . . . . 205

Socket Servers ............................... 212

Multicast and Unicast Servers . . . . . . . . . . . . . . . 212

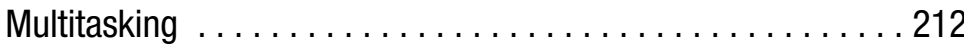

The Server Socket Class . . . . . . . . . . . . . . . 213

The Application Protocol . . . . . . . . . . . . . . . 218

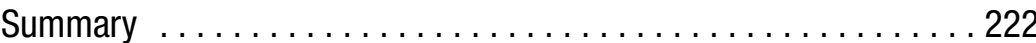

FAQs ...................................... 222

CHAPTER 8 The Graphical User Interfaces $\ldots \ldots \ldots \ldots \ldots \ldots \ldots \ldots 225$

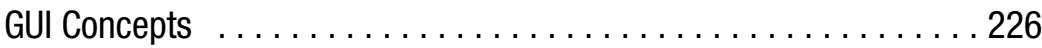

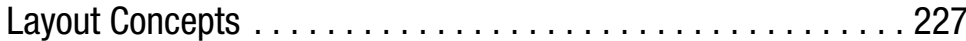

Human Interface Concepts . . . . . . . . . . . . . . . . 228

Model-View-Controller Pattern . . . . . . . . . . . . . . . . . . 234

Why Use the MVC Pattern? . . . . . . . . . . . . . . . . . 234

MVC in Detail ............................. 234

Benefits of MVC ........................ 236

Drawbacks of MVC ........................ 236

Alternatives to MVC ....................... 237

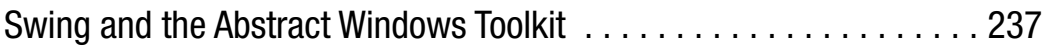

Layout Manager Overview $\ldots \ldots \ldots \ldots \ldots \ldots \ldots \ldots 237$

Look and Feel . . . . . . . . . . . . . . . . . . . . . . . 241

The JLabel Component . . . . . . . . . . . . . . . . . . . . . . . 244

The JTextField Component $\ldots \ldots \ldots \ldots \ldots \ldots \ldots \ldots . \ldots 245$

The JButton Component $\ldots \ldots \ldots \ldots \ldots \ldots \ldots \ldots \ldots \ldots 248$

The JRadioButton Component . . . . . . . . . . . . . . . . . 249

The JComboBox Component . . . . . . . . . . . . . . . . . . 251

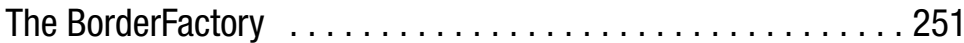

The JTable Component . . . . . . . . . . . . . . . . . . . . 254

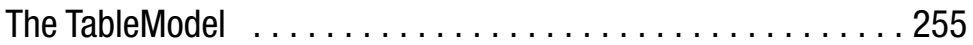

Using the TableModel with a JTable $\ldots \ldots \ldots \ldots \ldots \ldots 259$

The JScrollPane $\ldots \ldots \ldots \ldots \ldots \ldots \ldots \ldots \ldots \ldots \ldots$ 
Bringing Denny's DVDs Together . . . . . . . . . . . . . . . 262

Application Startup Class $\ldots \ldots \ldots \ldots \ldots \ldots \ldots \ldots . \ldots . \ldots . \ldots 262$

The Client GUI . . . . . . . . . . . . . . . . . . . . . . . . 263

Specifying the Database Location . . . . . . . . . . . . . . . 273

The Server GUl ......................... 286

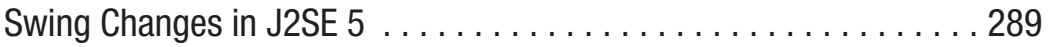

Improve Default Look and Feel of Swing . . . . . . . . . 289

Skins Look and Feel . . . . . . . . . . . . . . . . . . . . . . . . 290

Adding Components to Swing Containers Has

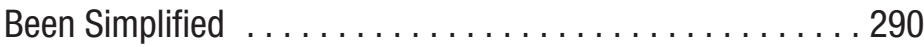

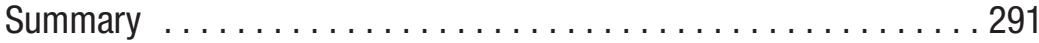

FAQs ...................................... 291

\section{PART $3 \backsim \square \square$ Wrap-Up}

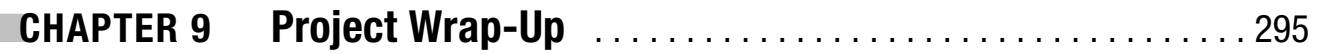

Thread Safety and Locking $\ldots \ldots \ldots \ldots \ldots \ldots \ldots \ldots \ldots \ldots$

The Choice Between RMl and Sockets ................ 296

Benefits of Using a Serialized Objects Over

Sockets Solution . . . . . . . . . . . . . . . . . . . . . 297

Benefits of Using an RMI Solution . . . . . . . . . . . . . . . 299

The MVC Pattern in the GUI . . . . . . . . . . . . . . . . 300

Locating the Code Samples . . . . . . . . . . . . . . . . . . . . . . 301

Compiling and Packaging the Application . . . . . . . . . . 301

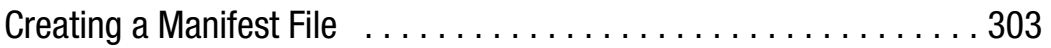

Running rmic on the Remote Package . . . . . . . . . . . . . . 304

Packaging the Application . . . . . . . . . . . . . . . . . . . . . 305

Running the Denny's DVDs Application $\ldots \ldots \ldots \ldots \ldots \ldots \ldots . \ldots 306$

Running the Client Application in Stand-alone Mode . . . . . . . 307

Running Denny's DVDs Server $\ldots \ldots \ldots \ldots \ldots \ldots \ldots \ldots$

Running the Client Application in Networked Mode . . . . . . . 309

Testing .................................... 309

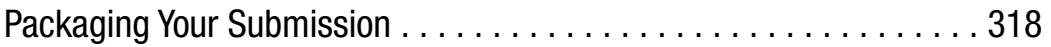

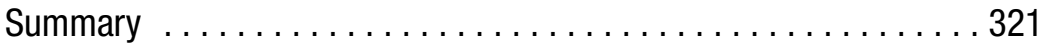

FAQs ..................................... 322

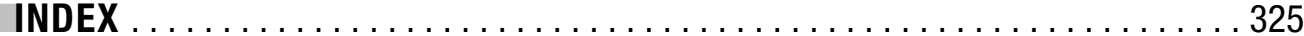




\section{About the Authors}

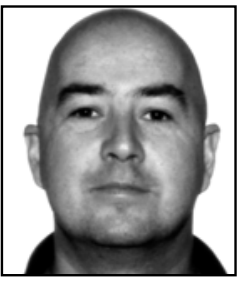

ANDREW MONKHOUSE is a moderator on the JavaRanch web site, currently moderating the SCJD and SCJA forums.

Andrew has passed SCJP 1.2, SCJP 1.4, SCJD, SCWCD, SCBCD, and Part I of SCEA. He has been working with computers for too long (his first program was written on mark-sense cards, which are similar to punch cards).

Andrew has worked in a number of positions from programmer, Microsoft operating systems. He's built back-end, middleware, and front-end solutions for a variety of industries. Andrew is an Australian at heart, although he is frequently in other countries for work purposes.

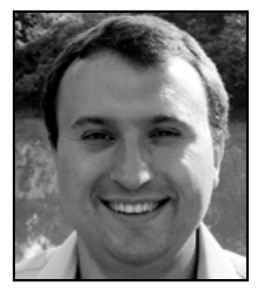

TERRY CAMERLENGO has over 9 years of software engineering experience from numerous corporations, including Fortune 500s and dot-coms. He is experienced in all phases of the software life cyle, with a focus on objectoriented technologies such as Java, C\#, C++, and .NET. His expertise includes front-end web design, server-side enterprise development, and relational database modeling and development. Terry holds both Sun and Microsoft certifications, and graduated with a degree in computer science and philosophy from Ohio State University. Currently Terry works for Ohio State University's James Cancer Center in the Biomedical Informatics department as a senior developer and research specialist and is pursuing advanced studies in computational biology. 


\section{About the Technical Reviewer}

JIM YINGST studied engineering physics at the University of Arizona, but after graduating he got sucked into the IT job market instead because, well, it seemed like a good idea at the time. He now roams the West helping tech companies find solutions to their IT problems.

Jim is a sheriff (administrator) and longtime contributor at www. javaranch.com, where his duties include answering Java questions, redirecting off-topic posts, and dealing with troublesome Australians.

He seems to spend most of his free time obsessively visiting bookstores. On rare occasions he actually reads the stuff he buys, mostly science fiction. The rest of the time he's probably listening to obscure progressive rock bands or finding new Thai restaurants. Jim lives in Boulder, Colorado. 


\section{Acknowledgments}

e would like to thank the following people:

- Mehran (Max) Habibi, who did so much work on the first edition and in getting this edition started, as well as introducing us to each other and to the Apress staff

- Our technical editor Jim Yingst, who not only verified our writing but made so many wonderful suggestions

- The fantastic staff at Apress for working with us on this project, and taking our raw work and producing a polished publication

- Each other

Without the help of all these people, this book would not be anywhere near as good as it is. We would also like to thank family, friends, and colleagues who put up with our bouncing between being totally unsociable when there were deadlines to meet, and desperately trying to catch up with everyone in the quiet times.

Andrew Monkhouse and Terry Camerlengo 


\section{Introduction}

he Sun Certified Developer for the Java 2 Platform assignment offers a unique opportunity for Java developers to put their Java skills to practical use without requiring any specific development or runtime environment. The assignment also provides a great learning environment as many different APIs can be used, and many alternative solutions can be provided. This book introduces many of the concepts you will need to know in order to pass the SCJD assignment.

Many developers are a little daunted by the scope of the assignment, as it covers everything from a back-end database, a server application, a front-end application, API documentation, and user documention. This book covers each section in detail, helping you gradually build up your knowledge of each topic while working toward a sample project. This book will also introduce you to the new features of JDK 5, providing contextual usage of the new APIs and features within our sample project.

The Sun assignment deliberately does not specify an operating system platform or development environment to be used-all that is needed is a computer capable of running a current version of the JDK. Throughout this book we have used JDK 5 on Windows 2000. Since this book introduces JDK 5 features, and uses them throughout our sample project, you will need JDK 5 to run our sample applications; however, the sample application is not dependent on Windows 2000.

We hope you enjoy this book, and we look forward to hearing that you passed and any comments you may have on this book. You can contact both authors at scjd@apress.com. 